\title{
Fever, cough and gastrointestinal symptoms in a pregnant woman
}

\author{
Authors: Nivedita Jha, ${ }^{\mathrm{A}}$ Divya M Balachandran ${ }^{\mathrm{B}}$ and Ajay K Jha ${ }^{\mathrm{C}}$
}

\begin{abstract}
Despite distinct diagnostic criteria, several gastrointestinal pathologies can masquerade haemophagocytic lymphohistiocytosis $(\mathrm{HLH})$ during the peripartum period. Acute fatty liver of pregnancy, HELLP (haemolysis, elevated liver enzymes and low platelets) syndrome, miliary tuberculosis, visceral leishmaniasis, abdominal surgical emergencies, haemolytic anaemias and haematological malignancies may have clinical and laboratory presentation similar to that of HLH. In this report, we present the case of a 26 -year-old woman with 38-weeks' gestation and abdominal pain, vomiting, intermittent fever and non-productive cough for 1-2 months. A thorough investigation suggested HLH and the patient was successfully treated with corticosteroids. This patient demonstrates the importance of a focused investigation strategy and timely management to prevent mortality and morbidity to both the mother and fetus in this rare and fatal disease.
\end{abstract}

KEYWORDS: haemophagocytic lymphohistiocytosis, pregnancy, corticosteroids, fever

DOI: 10.7861/clinmed.2021-0443

\section{Case presentation}

A 26-year-old woman (gravida 2, para 1; 1 live birth through caesarean delivery) presented at 38 weeks' gestation with intermittent highgrade fever and non-productive cough. She had had fever and cough for 1 month, and she took medications from a local physician. She also reported abdominal pain and infrequent episodes of vomiting. The pain was continuous and low grade for the previous 2 months. Before this, she had loss of appetite and less than usual weight gain with a progressive increase with gestation. She reported no chills, night sweats, haemoptysis, haematemesis, melaena, wheezing, exertional dyspnoea, chest pain, palpitation, headache or syncope. Previous pregnancy and the postpartum period were unrevealing. She and her family members did not have similar symptomatology previously, including childhood. She did not report alcohol or drug abuse.

Authors: ${ }^{A}$ assistant professor, Jawaharlal Institute of Postgraduate Medical Education and Research, Puducherry, India; ${ }^{\text {B }}$ senior resident, Jawaharlal Institute of Postgraduate Medical Education and Research, Puducherry, India; ' associate professor, Jawaharlal Institute of Postgraduate Medical Education and Research, Puducherry, India
On physical examination, her temperature was $39^{\circ} \mathrm{C}$, heart rate was 120 beats per minute, blood pressure was $100 / 60 \mathrm{mmHg}$, respiratory rate of 18 breaths per minute and oxygen saturation of $99 \%$ on room air. Pallor and icterus were noted in mucous membranes. Jugular venous pulse was normal, but she had bilateral pedal oedema present. She did not have cyanosis, clubbing, lymphadenopathy and rashes. The abdomen was gravid corresponded to 36 weeks of gestation, non-tender and had a healthy caesarean scar. Both liver and spleen were palpable well below the costal margin. Cardiovascular, respiratory, neurological and musculoskeletal examinations were normal.

\section{Investigations}

Differential diagnosis included several common medical and surgical pathologies: acute fatty liver of pregnancy, HELLP (haemolysis, elevated liver enzymes and low platelets) syndrome, miliary/ abdominal tuberculosis, haemolytic anaemia, visceral leishmaniasis and lymphomas. ${ }^{1-4}$ A complete blood count showed white cell counts of 3,000 cells $/ \mathrm{mm}^{3}$ (neutrophils; $65 \%$ ), platelet count of 94,000 cells $/ \mathrm{mm}^{3}$ and a haemoglobin level of $8.4 \mathrm{~g} / \mathrm{dL}$. Liver function tests revealed total bilirubin of $4.6 \mathrm{mg} / \mathrm{dL}$, direct bilirubin of $2.4 \mathrm{mg} / \mathrm{dL}$, aspartate aminotransferase of $122 \mathrm{U} / \mathrm{L}$ and alanine transferase of $30 \mathrm{U} / \mathrm{L}$. Serum albumin, prothrombin time and international normailised ratio were normal, while fibrinogen level was $133 \mathrm{mg} / \mathrm{dL}$. The metabolic profile revealed triglyceride level of $653 \mathrm{mg} / \mathrm{dL}$. Serum ferritin level was $1,852 \mathrm{ng} / \mathrm{mL}$. Renal functions were unremarkable. Ultrasound of the abdomen revealed the liver size of $15.4 \mathrm{~cm}$ and spleen size of $12.7 \mathrm{~cm}$. Blood and urine culture did not show bacterial growth. C-reactive protein and procalcitonin levels were $8 \mathrm{mg} / \mathrm{dL}$ and $0.5 \mathrm{ng} / \mathrm{mL}$. Infectious diseases workup included viral antibody (cytomegalovirus, Epstein-Barr virus and hepatitis), peripheral blood smear for malaria and nucleic acid amplification test for tuberculosis. All other infectious diseases work up (brucella, dengue, chikungunya and scrub typhus) were also unremarkable.

Furthermore, direct Coombs test and anti-nuclear antibody were negative. During workup and after 3 days of hospital admission, she delivered a small for gestational age (body weight of 2,100 g) girl. Her symptoms persisted, and she underwent contrast-enhanced computed tomography (CECT) and positron emission tomography (PET). CECT suggested massive splenomegaly and PET did not show any abnormal tracer uptake (Fig 1). Bone marrow examination was unremarkable.

\section{Diagnosis and management}

The key to correct diagnosis in this patient was that she fulfilled at least five diagnostic criteria: fever (temperature $>38.5^{\circ} \mathrm{C}>7$ days), 

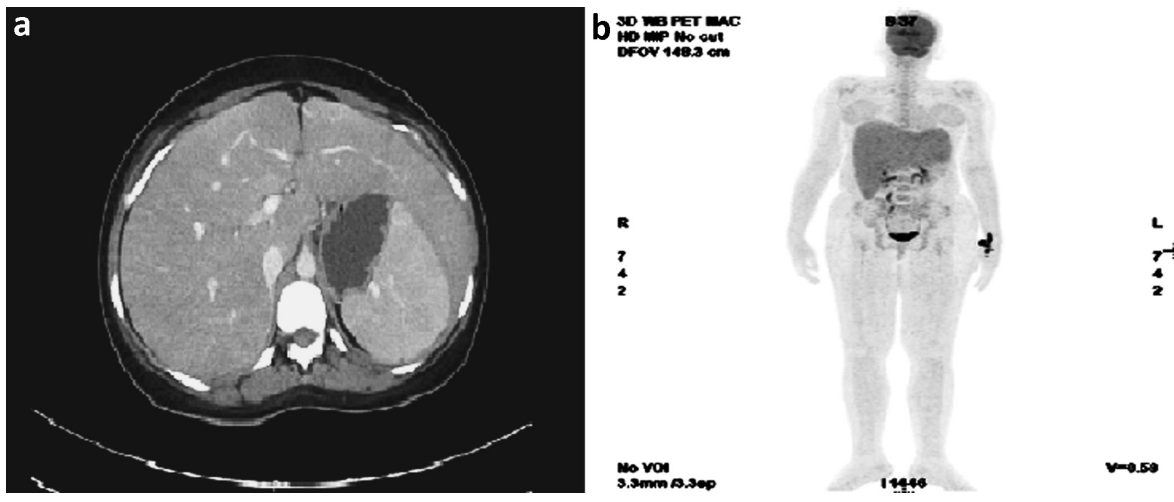

Fig 1. Postpartum imaging. a) Contrastenhanced computed tomography suggesting hepatosplenomegaly. b) Positron emission tomography using F18 fluorodeoxyglucose showing no focal abnormal tracer uptake; bilateral lung and visualised bone marrow are unremarkable.

Table 1. Differential diagnosis of fever with gastrointestinal dysfunction during pregnancy

\begin{tabular}{|c|c|c|c|c|c|c|c|c|}
\hline & $\begin{array}{l}\text { HLH } \\
\text { (in this } \\
\text { patient) }\end{array}$ & $\begin{array}{l}\text { Acute fatty } \\
\text { liver }\end{array}$ & $\begin{array}{l}\text { HELLP } \\
\text { syndrome }\end{array}$ & $\begin{array}{l}\text { Visceral } \\
\text { leishmaniasis }\end{array}$ & $\begin{array}{l}\text { Miliary/ } \\
\text { abdominal } \\
\text { tuberculosis }\end{array}$ & $\begin{array}{l}\text { Haemolytic } \\
\text { anaemias }\end{array}$ & $\begin{array}{l}\text { Chronic } \\
\text { hepatitis }\end{array}$ & Lymphomas \\
\hline Fever & Yes & Yes, rarely & No & Yes & Yes & $\begin{array}{l}\text { Yes, } \\
\text { infrequent }\end{array}$ & Yes & Yes \\
\hline Abdominal pain & Yes & Yes & Yes & Yes & Yes & $\begin{array}{l}\text { Yes, splenic } \\
\text { infarct }\end{array}$ & Yes & Yes \\
\hline Vomiting & Yes & Yes & Yes & Yes & Yes & No & Yes & No \\
\hline $\begin{array}{l}\text { Neurological } \\
\text { symptoms }\end{array}$ & No & Yes & Yes & Yes, rarely & Yes & Yes & Yes & No \\
\hline Splenomegaly & Yes & No & No & Yes & Yes & Yes & Yes & Yes \\
\hline Hepatomegaly & Yes & No & No & Yes & Yes & No & No & Yes \\
\hline Liver dysfunction & Yes & Yes & Yes & No & $\begin{array}{l}\text { Yes, anti- } \\
\text { tubercular } \\
\text { medications }\end{array}$ & Yes & Yes & Yes \\
\hline $\begin{array}{l}\text { Coagulation } \\
\text { abnormalities }\end{array}$ & No & Yes & Yes & No & No & No & Yes & $\begin{array}{l}\text { Yes, in } \\
\text { advanced } \\
\text { stages }\end{array}$ \\
\hline Anaemia & Yes & Yes, haemolysis & $\begin{array}{l}\text { Yes, occa- } \\
\text { sionally }\end{array}$ & Yes & $\begin{array}{l}\text { Yes, } \\
\text { infrequently }\end{array}$ & Yes & Yes & Yes \\
\hline $\begin{array}{l}\text { Thrombocy- } \\
\text { topenia }\end{array}$ & Yes & Yes & Yes & Yes & $\begin{array}{l}\text { Yes, } \\
\text { infrequently }\end{array}$ & Yes & Yes & $\begin{array}{l}\text { Yes, rarely } \\
\text { immune } \\
\text { mediated }\end{array}$ \\
\hline Leukopenia & Yes & Yes, leukocytosis & No & No & $\begin{array}{l}\text { Yes, rarely, } \\
\text { leukocytosis } \\
\text { common }\end{array}$ & No & No & $\begin{array}{l}\text { Yes, } \\
\text { leukocytosis } \\
\text { more } \\
\text { common than } \\
\text { leukopenia }\end{array}$ \\
\hline $\begin{array}{l}\text { High serum } \\
\text { ferritin }\end{array}$ & Yes & No & No & No & Yes, rarely & Yes, rarely & $\begin{array}{l}\text { Yes, only in } \\
\text { advanced } \\
\text { cirrhosis }\end{array}$ & Yes \\
\hline $\begin{array}{l}\text { High serum } \\
\text { triglyceride }\end{array}$ & Yes & $\begin{array}{l}\text { Yes, infrequently, } \\
\text { mainly } \\
\text { hypercholes- } \\
\text { terolemia }\end{array}$ & No & No & $\begin{array}{l}\text { Yes, extremely } \\
\text { rare }\end{array}$ & No & $\begin{array}{l}\text { Yes, } \\
\text { infrequently }\end{array}$ & Yes, rarely \\
\hline $\begin{array}{l}\text { Low serum } \\
\text { fibrinogen }\end{array}$ & Yes & Yes & Yes & No & Yes, rarely & No & Yes & $\begin{array}{l}\text { Yes, advanced } \\
\text { stages }\end{array}$ \\
\hline
\end{tabular}

HLH = haemophagocytic lymphohistiocytosis; HELLP = haemolysis, elevated liver enzymes and low platelets 
splenomegaly (spleen was palpable $>3 \mathrm{~cm}$ below costal margin), cytopenia involving more than two cell lines (haemoglobin $<9 \mathrm{~g} / \mathrm{dL}$; platelet count $<105 \mu \mathrm{L}$ ), hypertriglyceridaemia (fasting triglycerides $>177 \mathrm{mg} / \mathrm{dL}$ ) and hypofibrinogenaemia (fibrinogen $<150 \mathrm{mg} / \mathrm{dL}$; serum ferritin $>500 \mathrm{ng} / \mathrm{mL}$ ). ${ }^{5,6}$ However, her bone marrow examination did not reveal haemophagocytes. Furthermore, soluble CD25 estimation and natural killer (NK) cell activity were not considered essential, as the patient already had necessary criteria. Biopsy of liver, spleen or lymph nodes could not have revealed any extra information to change the diagnosis. Additionally, direct agglutination test for visceral leishmaniasis would have been less useful in this scenario as diagnostic criteria of $\mathrm{HLH}$ indicated early administration of corticosteroids. Moreover, despite extensive workup, we could not identify any trigger for $\mathrm{HLH}$ in this patient, and genetic predisposition is highly unlikely as she manifested only during her second pregnancy. She was treated with intravenous dexamethasone ( $4 \mathrm{mg}$ three times daily) and oral ampicillin and clavulanic acid, vitamin B complexes and paracetamol.

\section{Discussion}

$\mathrm{HLH}$ is a fatal disease, and mortality for acquired HLH exceeds $50 \%{ }^{7}$ Despite distinct diagnostic criteria, several gastrointestinal pathologies can masquerade HLH during pregnancy and the postpartum period. ${ }^{8}$

$\mathrm{HLH}$ is characterised by the unregulated immune response due to several potential triggers. It may be aggressive and causes lifethreatening multiorgan dysfunction and may lead to substantial morbidity and mortality. In both inherited or acquired $\mathrm{HLH}$, an impaired cytolytic function of NK cells and CD8+ T cells is mainly responsible for sustained release of pro-inflammatory cytokines and accumulation of T cells and histiocytes. ${ }^{9}$

Clinical manifestation may begin with intermittent fever and signs and symptoms suggestive of liver function abnormalities. Haematological manifestation includes pancytopenia, presence of haemophagocytes in bone marrow aspirate, low NK cell activity and soluble CD25. Other infrequently observed clinical and laboratory abnormalities include lymphadenopathy, rash, neurological symptoms, and an elevated ferritin and triglyceride level.

Overlapping of diagnostic parameters pose a serious challenge in excluding HLH from other clinical entities (Table 1). ${ }^{1-4}$ Furthermore, management in each of these clinical diseases is entirely different. High-dose corticosteroids, etoposide, cyclosporin, rituximab and intravenous immunoglobulin have been used successfully to treat acquired $\mathrm{HLH} .^{10}$ However, the safety and efficacy of etoposide, cyclosporin, rituximab and immunoglobin during pregnancy and lactation are yet to be established.

\section{Patient outcome and follow-up}

The patient improved symptomatically and became afebrile in the next 7 days and her laboratory parameters returned to normal. She was discharged from the hospital after 15 days. She was later readmitted again to the hospital with recurrence of symptoms (Fig 2). Dexamethasone was continued intravenously (18 mg per day). She improved again in following 5 days and was discharged from the hospital with continued tapering prescription of dexamethasone. Dexamethasone was stopped after 45 days of the second hospitalisation. She was completely asymptomatic when was followed up 2 months later.

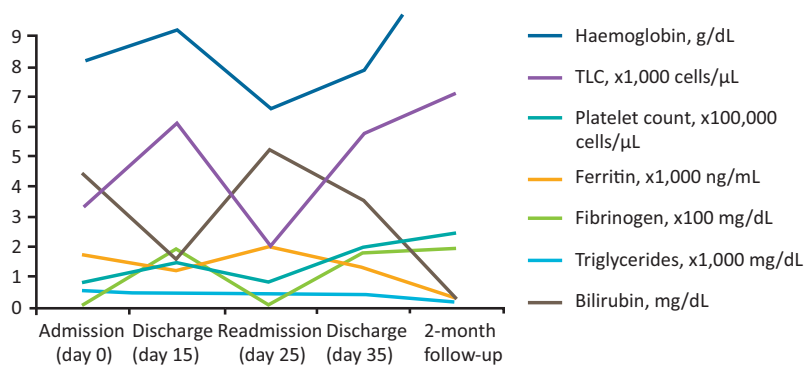

Fig 2. Timeline of changes in laboratory parameters from admission to discharge and follow-up at the end of $\mathbf{2}$ months (delivery was on day 3 of admission). TLC = total leukocyte count.

\section{Key points}

> Acquired haemophagocytic lymphohstiocytosis is a fatal disease requiring thorough clinical examination and focssed investigation.

> Consider several differentials when a pregnant woman presents with fever and gastrointestinal symptoms.

$>$ Correct diagnosis is paramount as management strategy widely differs across mimicks.

$>$ Early initiation of corticosteroids may prevent maternal and fetal mortality.

\section{References}

1 Dusse LM, Alpoim PN, Silva JT et al. Revisiting HELLP syndrome. Clin Chim Acta 2015;451:117-20.

2 Naoum EE, Leffert LR, Chitilian HV, Gray KJ, Bateman BT. Acute fatty liver of pregnancy: pathophysiology, anesthetic implications, and obstetrical management. Anesthesiology 2019;130:446-61.

3 van Griensven J, Diro E. Visceral leishmaniasis. Infect Dis Clin North Am 2012:26:309-22.

4 Rasheed S, Zinicola R, Watson D, Bajwa A, McDonald PJ. Intraabdominal and gastrointestinal tuberculosis. Colorectal Dis 2007;9:773-83.

5 Henter JI, Elinder G, Ost A. Diagnostic guidelines for hemophagocytic lymphohistiocytosis. The FHL Study Group of the Histiocyte Society. Semin Oncol 1991;18:29-33.

6 Henter JI, Horne A, Aricó M et al. HLH-2004: Diagnostic and therapeutic guidelines for hemophagocytic lymphohistiocytosis. Pediatr Blood Cancer 2007:48:124-31.

7 Janka G, Imashuku S, Elinder G, Schneider M, Henter JI. Infectionand malignancy-associated hemophagocytic syndromes. Secondary hemophagocytic lymphohistiocytosis. Hematol Oncol Clin North Am 1998;12:435-44.

8 Rosado FG, Kim AS. Hemophagocytic lymphohistiocytosis: an update on diagnosis and pathogenesis. Am J Clin Pathol 2013;139:713-27.

9 Al-Samkari H, Berliner N. Hemophagocytic Lymphohistiocytosis. Annu Rev Pathol 2018;13:27-49.

10 Dunn T, Cho M, Medeiros B et al. Hemophagocytic lymphohistiocytosis in pregnancy: a case report and review of treatment options. Hematology 2012;17:325-8.

Address for correspondence: Dr Ajay Kumar Jha, Department of Anaesthesiology and Critical Care, Jawaharlal Institute of Postgraduate Medical Education and Research, JIPMER Campus Road, Gorimedu, Puducherry 605006, India.

Email: drajaykjha@rediffmail.com

Twitter: @AjayJha_1212 